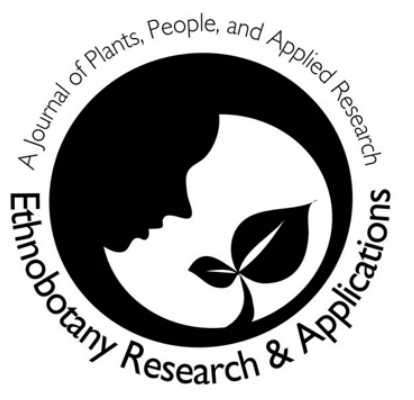

\title{
Medicinal plants used against gastrointestinal complaints in district Budgam of Jammu and Kashmir - An ethnomedicinal study
}

Tawseef Ahmad Mir, Rakesh Kumar Khare and Muatasim Jan

\author{
Correspondence \\ Tawseef Ahmad Mir*, Rakesh Kumar Khare and Muatasim Jan \\ Centre of Research for Ethnobotany, Government Model Science College, Jiwaji University, Gwalior, India-474009 \\ *Corresponding Author: mirtawseef787@gmail.com
}

Ethnobotany Research \& Applications 22:11 (2021)

\section{Research}

\begin{abstract}
Background: The current study was the first to target on gastrointestinal illnesses and associated traditional recipes in Jammu and Kashmir's Budgam area. Gastrointestinal disorders affect any part of the gastrointestinal system, from the esophagus to the rectum, as well as the accessory digestive organs. The knowledge about plants used for the treatment gastrointestinal disorders is rapidly depleting in the study area and hence it becomes important to document this valuable knowledge.
\end{abstract}

Methods: Extensive surveys were conducted in the study area during March 2019 to July 2020 for the collection of medicinally important plants and the traditional knowledge associated with them. In a total 35 informants (22 males, 13 females) were interviewed aged between 29-80 years to collect the data using group discussions and semi-structured interviews. The interviews were carried out in local dialect and all the documented data was then translated into English. Various ethnobotanical indices, including informant consensus factor and use value, were employed to evaluate the gathered information.

Results: A total of 56 plant species belonging to 24 families and 47 genera were reported to be used against gastrointestinal disorders in Budgam region of Jammu and Kashmir. Among 24 families, Asteraceae was the dominant family (12 species) of the total reported taxa in the study area and leaves were the most utilized plant part with decoction as the major mode of herbal recipe preparation. Highest ICF (Informant consensus factor) of 1 was reported for vomiting and Artemisia absinthium recorded the highest UV (Use value) of 0.74.

Conclusion: Local inhabitants still prioritize herbal medicines as an effective way to treat a wide variety of ailments. Elders of the study area are well equipped with indigenous knowledge about medicinal plants, but young people are not much interested in herbal practices. Thus, valuable knowledge about the use of plants is on the verge of decline. Hence there is a dire need to document these valuable medicinal plants and the traditional treasure associated with them. In addition, plants reported with high UV should be subjected for further phytochemical and pharmacological investigation to authenticate indigenous uses.

Keywords: Medicinal plants, Ethnomedicine, Traditional knowledge, Gastrointestinal complaints, Budgam, J\&K. 


\section{Background}

Plants are a significant resource of conventional medicines used against numerous diseases. Rural people who have century's old traditional knowledge transmitted from generation to generation still rely on plant resources for variety of uses such as food, fodder, and medicines. Due to a lack of modern medical facilities, residents in rural areas rely primarily on natural resources (Tali et al. 2019). More than $80 \%$ of the world's population relies on traditional medicines for health care, but it is now limited to rural regions due to a shift in people's attitudes toward contemporary health care in urban areas, as well as changing living patterns over time (Hocking 1958; lbrar et al. 2007; Msomi and Simelane 2019). Modernization in rural cultures has put this centuries-old traditional knowledge in jeopardy. In India, a lot of tribal people from various ethnic origins live and follow their own traditional medical system for basic healthcare. According to reports, $80 \%$ of Indians consume non-allopathic (Ayurveda, Siddha, Unani, and Homeopathy) medications for their health, and herbs are a key component of these alternative medical systems (Gogtay et al. 2002). In India, major health hazards include widespread communicable diseases, inadequate sewage infrastructure, and a lack of safe drinking water (Jeelani et al. 2018). Inadequate nutrition and exposure to contaminated water are responsible for the high newborn morbidity and death rates (Woods 1991). Most of the infectious diseases are caused by microorganisms. Antibiotic resistance, on the other hand, is a serious clinical issue when it comes to treating illnesses caused by these bacteria. Dysentery, Stomach pain, Diarrhea, Constipation, Indigestion, Abdominal pain, Intestinal worms, Acidity etc. are some of the major gastrointestinal problems in today's population. Proton pump inhibitors, H2 receptors, cytoprotectants, demulcents, anticholinergics, antacids, and prostaglandin analogues are some of the synthetic medicines used to treat these problems (Acharyya et al. 2009). Besides, these medicines are responsible to treat an ailment in a short span of time, but they have several side effects. A number of secondary ailments take birth by the use or overuse of these medicines including, nausea, dizziness and sometimes the death of the fetus in mother's womb (Ishtiyak and Hussain 2017). Herbal treatments are thought to be more effective therapeutic options. Proton pump inhibitors (omeprazole, lansoprazole), for example, might induce nausea, abdominal pain, constipation, and diarrhea, and $\mathrm{H} 2$ receptor antagonists (cimetidine) can cause gynecomastia and libido loss. Due to the numerous adverse effects associated with the use of synthetic medicines for a variety of ailments, medicinal plants are increasingly being regarded as a primary source of novel pharmaceuticals, and significant research is conducted in quest of strong plant-based treatments (Savikin et al. 2013). However, sometimes the higher doses may cause serious implications or even death of the soul. If not taken in proper doses these plants may pose adverse effects on the human body (Holst et al. 2008). That is why, one need to be more sensitive while using the herbal medicinal plants at home. In India and other places, medicinal plants are utilized to treat gastrointestinal problems including diarrhea and dysentery. However, no such study has been conducted in Jammu \& Kashmir's Budgam region. The current study was the first to target on gastrointestinal illnesses and associated traditional recipes in Jammu and Kashmir's Budgam area. In addition, the medicinal plants and the associated knowledge is degrading and is on the verge of extinction, so our study also attempts to conserve this degrading flora and the associated knowledge.

In this study we sought to discover answers to the following questions concerning medicinal plants used to treat gastrointestinal complaints: (i) Which species are utilized locally in the treatment of gastrointestinal disorders? (ii) Which sort of gastrointestinal disorder does a certain herb treat? (iii) Which part of the plant is used for medicinal purposes? (iv) What is the mode of administration of the drug? Furthermore, the data was analyzed by using various ethnobotanical indices to determine the more useful plants of the area which can be subjected to further pharmacological and phytochemical analysis.

\section{Material and methods \\ Study area}

Current study was carried out in district Budgam of Jammu and Kashmir (Fig. 1). It is located in the Northwestern section of the greater Himalaya, between $34^{\circ} 40^{\prime}$ and 34 $80^{\prime}$ north latitude and $74^{\circ} 24^{\prime}$ to $74^{\circ} 56^{\prime}$ east longitude (Fig. 1). Bounded by dense forests, it is situated about $25 \mathrm{Kms}$ from capital city Srinagar in the mountains of the Himalayan range. It covers $1,370 \mathrm{~km}^{2}$ and accounts for 1.35 percent of Jammu and Kashmir's overall land area. The average elevation in the district is $\mathbf{1 6 1 0}$ meters above sea level. Sky-touching deodars fence this area presenting a view of a green carpet in summer. During the summer, the camps of the Gujjar community and shepherds with their grazing sheep present a riveting picture. Also, the fragrance of wildflowers refreshes the whole environment. During the winters the study area faces severe cold and a pleasant weather during summers. The temperature ranges between $-4^{\circ} \mathrm{C}$ minimum in winter and up to $32^{\circ} \mathrm{C}$ maximum in summers (Ahmad and Qayoom 2019). 


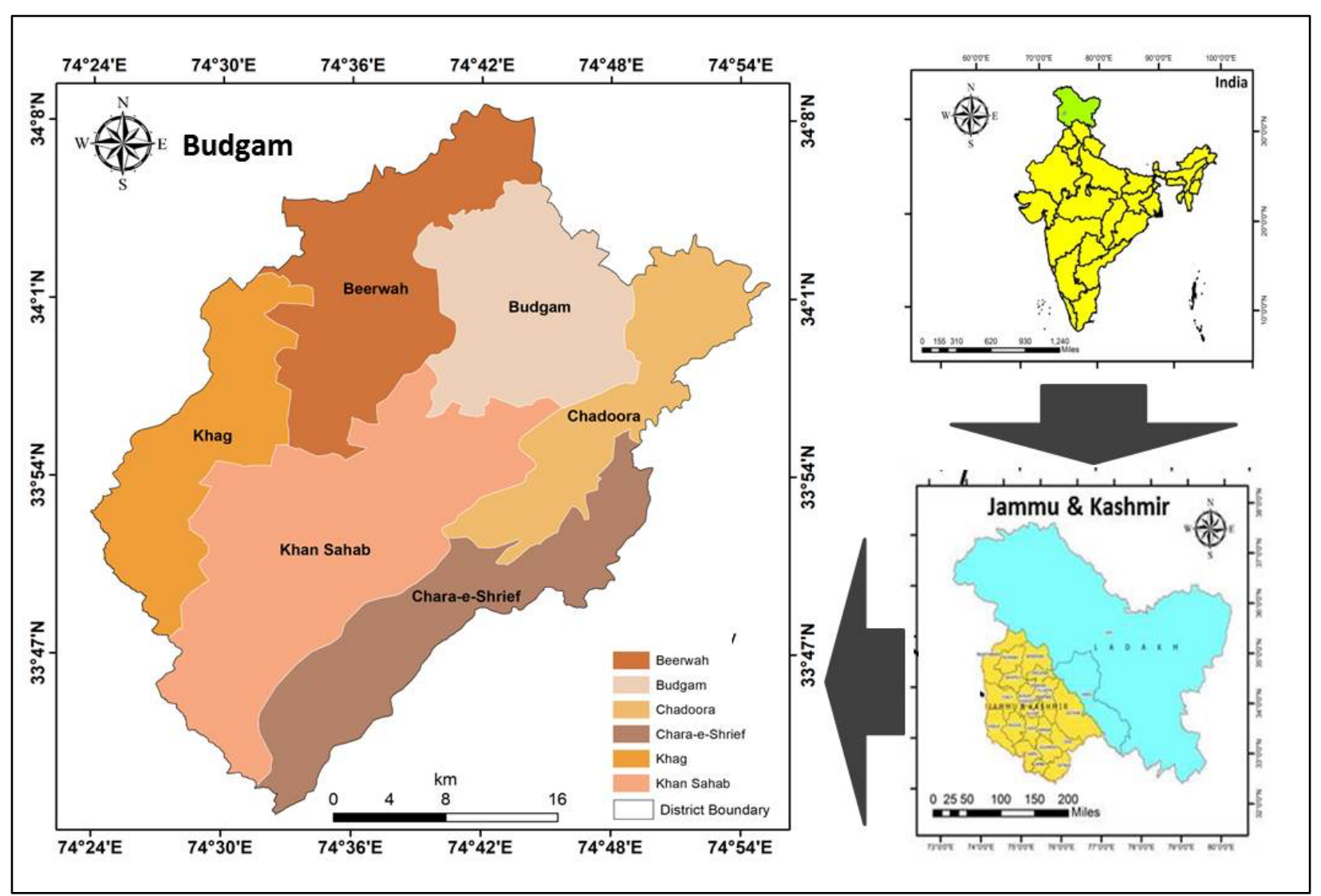

Figure 1. Map highlighting the study area, District Budgam, Jammu and Kashmir.

A total of 32 visits with each visit of 2 days was made to the study area to collect the plants and information from total 14 sites (Arizal, Chak Hokalatri, Faja Pora, Machi Pora, Badran, Khahi Pora, Larik Pora, Ramdar Chakpora, Peth Saharan, Kanchati Pora, Brenpathri, Gund Shamus, Bupat, and Dragar) richly populated with ethnic communities, where these people are solely dependent on medicinal plants to cure a variety of diseases. Plants were collected with the help of local guides who were aware about the region. Plants with mature leaves, stem, roots and flowers were selected for collection. Agriculture (animal husbandry and crop production) is the main source of livelihood for these people in the region.

\section{Sample size determination}

A probabilistic approach was employed considering simple and stratified random sampling methods (Levy and Lemeshow 2008). Given the demographic details (Table 1) of the families studied, we were able to determine the sample size using a simple random sampling method.

\section{Data collection tools}

The use of plant-based medicine to cure various diseases is a widely accepted system by the local communities of district Budgam upper reaches. Extensive surveys were conducted in the study area from March 2019 to July 2020 for the collection of medicinally important plants and the traditional knowledge associated with them. Before the commencement of the study, village heads were visited. Informants were interviewed through different types of interview methods including semi-structured interviews and group discussions by using standard questionnaire (Martin 1995). Brief group discussions were held with the informants prior to the interview to explain the objective of the study and a formal consent was taken from all the informants. The interviews were carried out in local dialect and all the documented data was then translated into English language. Guided field walk was also performed to the forest area, which allowed us to collect best possible information about the identification and utilization of important medicinal plant species. The information collected included local name of the plant, life form, part used, ethnomedicinal use, method of preparation and administration. During the interviews, a total of 4 informants refused to take part in the study citing the issues of personal data sharing. In place of these four, we selected another exact sum. 
Table 1. Demographic status of informants.

\begin{tabular}{|c|c|c|}
\hline Variable & Total & Percentage \\
\hline \multicolumn{3}{|l|}{ Gender } \\
\hline Male & 22 & 63 \\
\hline Female & 13 & 37 \\
\hline \multicolumn{3}{|l|}{ Age groups } \\
\hline $29-40$ & 4 & 11 \\
\hline $41-50$ & 6 & 17 \\
\hline $51-60$ & 5 & 17 \\
\hline $61-70$ & 8 & 23 \\
\hline $71-80$ & 12 & 34 \\
\hline \multicolumn{3}{|c|}{ Educational qualification } \\
\hline Illiterate & 22 & 63 \\
\hline Primary & 5 & 14 \\
\hline Secondary & 4 & 11 \\
\hline Above secondary & 4 & 11 \\
\hline \multicolumn{3}{|l|}{ Occupation } \\
\hline \multicolumn{3}{|l|}{ Males } \\
\hline Shopkeepers & 6 & 17 \\
\hline Farmers & 13 & 37 \\
\hline Job holders & 3 & 9 \\
\hline \multicolumn{3}{|l|}{ Females } \\
\hline Housewives & 11 & 31 \\
\hline Job holders & 2 & 6 \\
\hline \multicolumn{3}{|l|}{ Religion } \\
\hline Muslim & 35 & 100 \\
\hline
\end{tabular}

Piloting, Validity and Reliability of data collection tools A four-day reconnaissance tour was performed to obtain a basic idea of the study's possible respondent. Following the initial visit, a week was spent preparing interviews and questionnaires for the survey, followed by another week of teaching research assistants on how to use the instruments successfully. Whenever necessary, the services of a translator were used. The results of the pilot were used to improve efficiency of the data collection tools for the main survey.

A questionnaire was created and sent to ethnobotany experts for cross-checking and analyzing the content's dependence to examine the validity of the data collection tools. The split half approach was used to test the reliability of data collection tools during the pilot, and the Cronbach alpha coefficient was calculated (Taber 2018). The tools were distributed to 24 family heads, divided into two groups. The reliability of items was determined by estimating the variability of responses between the two groups.

\section{Preservation and identification of collected plants}

The medicinal plant species reported by informants were collected during field trips guided by local people. The specimens were dried, pressed and mounted on herbarium sheets and good quality voucher specimens were made according to standard techniques (Jain and Rao 1997). For identification, plant specimens and usable pieces were also collected. Flora of Jammu and Kashmir (Singh et al. 2002), Flowers of the Himalayas (Polunin and Stainton 1984), and Flora of the Pir Panjal range of the north-west Himalaya were used to identify the plant species (Singh and Kachroo 1994). Additional identification was carried out by matching voucher specimens with previously identified specimens deposited in KASH Herbarium of Department of Botany, University of Kashmir, Srinagar. Herbarium specimens and plant parts collected during this study have been deposited in thementioned herbarium for future references. The botanical names of the plant species were updated according to the Plant List (www.theplantlist.org). A comparative assessment through literature review on the subject was made to ascertain new findings of ethomedicinally important plants.

\section{Determination of informant consensus factor and use value}

The informant consensus factor was used to determine whether the informants agreed on which plant species to use for each ailment category. The informant consensus factor shows which plants are often used, which may help with plant selection for potential phytochemical and pharmacological research (Giday et al. 2007). To check the informant consensus factor in this study, all the diseases were grouped into different ailment categories. The ICF value varies from 0 to 1 . A high value (1.0 or close to 1 ) indicates that a large proportion of the informants use a relatively small number of plant species. The low value, on the other hand, indicates that the informants disagree about the usage of plant species within a specific ailment group. ICF was calculated using the following formula (Heinrich et al. 1998).

$$
I C F=\frac{N u r-N t}{N u r-1}
$$

Where Nur denotes the total number of usage reports for a given ailment category and $N t$ is the total number of species used by all informants for that particular ailment type.

The use value index is used to calculate the relative value of each medicinal plant species used by the local population. In the current study use value was calculated using the following formula:

$$
U V=\frac{U i}{N}
$$


Where $\mathrm{Vi}$ is the total number of use reports by each informant and $N$ shows the total number of informants taking part in the study (Phillips and Gentry 1993). Use value is high when there are many use reports for a given medicinal plant species and use value is low when there are very few reports associated with its use.

\section{Data analysis}

Data were entered into Microsoft word version 2010 and thereafter transferred to Microsoft excel version 2010 for further analysis. Descriptive statistics (simple percentages, tables and figures) were employed in the excel 2010. The data was then summarized using different graphical methods (bar and pie charts).

\section{Results and Discussions}

\section{Demographic details of informants}

To explore the traditional knowledge regarding the ethnomedicinal uses of plant species in the area, a total of 35 informants (22 men, 13 women) were interviewed aged between 29-80 years (Table 1). Among these, male informants (22 informants) were found to have more experience in terms of knowledge sharing than female informants (13 informants). Most of the selected informants were illiterate, and a small number were having education up to higher secondary level and few were job holders. All the selected informants were of one religion (Muslims), as it is the most practiced religion of the area. Gujri, Pahari, and Kashmiri are the three main languages of communication. The informants were selected based on their traditional knowledge about the use of plants for treating various diseases. To ensure the validity of traditional knowledge, continuous relationship was maintained with the local population throughout the survey course.

The informants above the age of 50 were found to be more informed. Other writers confirmed similar findings (Ayantunde et al. 2008; Ahmad and Pieroni 2016; Jan et al. 2017). Most of the people reported also share experiences of other people about the use of medicinal plants. The dissemination of traditional knowledge, on the other hand, was found to be jeopardized since the younger generation had less interest in studying and consequently knew less about medicinal plants. Other researchers reported similar findings (Mehdioui and Kahouadji 2007; Ayantunde et al. 2008).

\section{Diversity of ethnomedicinal flora}

During the present study a total of 56 medicinally important plant species belonging to 24 families and 47 genera were reported to be used for gastrointestinal disorders in Budgam region of Jammu and Kashmir (Table 2). A total of 8 species, Allium cepa, Coriandrum sativum, Daucus carota, Foeniculum vulgare, Mentha arvensis, Trigonella foenum-graecum, Ficus carica, Cyndonia oblonga and Solanum tuberosum were belonging to domesticated and cultivated categories and rest were wild species. Medicinal plants are generally harvested from nearby forest areas by the local people. However, to collect high altitude species people need to travel some $15-20 \mathrm{~km}$ by foot. The reported species were represented by 24 families. Among 24 families, Asteraceae was the dominant family (12 species) of the total reported taxa followed by Lamiaceae (8 species), Amaranthaceae and Malvaceae (4 species each) (Fig. 2).

Our results were in line with previous studies where Asteraceae has been reported as the dominant medicinal plant family in various other study regions (Bhatia et al. 2014; Bolson et al. 2015; Ishtiyak and Hussain 2017; Jan et al. $2021 a, b)$. The reason behind the dominance of the family Asteraceae is that members of this family are well known for aromatic quality and are easily available in nature or might be due to its herbaceous life form, extensive distribution, and richness in the study area (Tariq et al. 2018; Shedayi and Bibi 2012). Furthermore, Asteraceae has been reported to contain many bioactive compounds used against different ailments (Leonti et al. 2003; Hamill et al. 2000). Also plants like Mentha arvensis Daucus carota, Trigonella foenum-graecum, Ficus carica, Cyndonia oblonga, Artemisia absinthium, and Acorus calamus contain a number of phenolic compounds, essential oils and other flavonoids which are useful for the treatment of gastrointestinal disorders and have antioxidant properties (Hussain et al. 2011; Nour et al. 2019; Bahukhandi et al. 2021). Local people believed raw materials collected from dense forests or the areas less accessible by humans had better efficacy. 
Ethnobotany Research and Applications

Table 2. Enumeration of plant species used by local people in district Budgam of Jammu and Kashmir against gastrointestinal disorders.

\begin{tabular}{|c|c|c|c|c|c|c|c|c|c|c|}
\hline Family & $\begin{array}{l}\text { Botanical name / } \\
\text { Voucher number }\end{array}$ & $\begin{array}{l}\text { Vernacular } \\
\text { name }\end{array}$ & $\begin{array}{l}\text { Life } \\
\text { form }\end{array}$ & Source & Part used & Preparation & Administration & Disease treated & $\begin{array}{l}\text { Total } \\
\text { citations }\end{array}$ & Use value \\
\hline \multirow[t]{4}{*}{ Amaranthaceae } & $\begin{array}{l}\text { Achyranthes aspera } \mathrm{L} . \\
\text { 3353-KASH }\end{array}$ & Phutkunda & Herb & WL & Whole plant & Decoction & Oral & Dysentery & 24 & 0.69 \\
\hline & $\begin{array}{l}\text { Amaranthus blitum L. } \\
\text { 3360-(KASH) }\end{array}$ & NA & Herb & $W L$ & Leaf & Cooked & Oral & Stomach pain & 21 & 0.60 \\
\hline & $\begin{array}{l}\text { Amaranthus caudatus L. } \\
\text { 3361-KASH }\end{array}$ & Liss & Herb & WL & Leaf & Decoction & Oral & Diarrhea & 19 & 0.54 \\
\hline & $\begin{array}{l}\text { Amaranthus spinosus L. } \\
\text { 3362-KASH }\end{array}$ & Liss & Herb & WL & Aerial portion & Cooked & Oral & Constipation & 20 & 0.57 \\
\hline Amaryllidaceae & $\begin{array}{l}\text { Allium cepa } \mathrm{L} . \\
\text { 3358-KASH }\end{array}$ & Gande & Herb & $\mathrm{CL}$ & Blub & Raw & Oral & Stomach pain & 18 & 0.51 \\
\hline \multirow[t]{3}{*}{ Apiaceae } & $\begin{array}{l}\text { Coriandrum sativum L. } \\
2975-\mathrm{KASH}\end{array}$ & Daniwal & Herb & $\mathrm{CL}$ & Seed & Decoction & Oral & Indigestion & 22 & 0.63 \\
\hline & $\begin{array}{l}\text { Daucus carota L. } \\
\text { 3390-KASH }\end{array}$ & Gazar & Herb & $\mathrm{CL}$ & Leaf & Juice & Oral & Dysentery & 21 & 0.60 \\
\hline & $\begin{array}{l}\text { Foeniculum vulgare Mill. } \\
\text { 3397-KASH }\end{array}$ & Badiyan & Herb & $\mathrm{CL}$ & Whole plant & Juice & Oral & Constipation & 23 & 0.66 \\
\hline Araceae & $\begin{array}{l}\text { Acorus calamus } \mathrm{L} . \\
3365-\mathrm{KASH}\end{array}$ & Vai & Herb & WL & Rhizome & Infusion & Oral & Abdominal pain & 19 & 0.54 \\
\hline \multirow[t]{9}{*}{ Asteraceae } & $\begin{array}{l}\text { Achillea millefolium L. } \\
\text { 2966-KASH }\end{array}$ & Pahal gass & Herb & WL & Leaf & Infusion & Oral & Dysentery & 13 & 0.37 \\
\hline & $\begin{array}{l}\text { Artemisia absinthium L. } \\
\text { 2969-KASH }\end{array}$ & Tethwan & Herb & WL & Leaf & Infusion & Oral & Intestinal worms & 26 & 0.74 \\
\hline & $\begin{array}{l}\text { Artemisia annua } \mathrm{L} . \\
\text { 3368-KASH }\end{array}$ & NA & Herb & WL & Root & Infusion & Oral & Abdominal pain & 17 & 0.49 \\
\hline & $\begin{array}{l}\text { Artemisia moorcroftiana Wall. ex } \\
\text { DC } \\
\text { 3369-KASH }\end{array}$ & Jangli-tethwan & Herb & WL & Whole plant & Decoction & Oral & Acidity & 12 & 0.34 \\
\hline & $\begin{array}{l}\text { Bidens pilosa } \mathrm{L} . \\
\text { 3373-KASH }\end{array}$ & Kumber & Herb & WL & Leaf & Powder & Oral & Stomach pain & 12 & 0.34 \\
\hline & $\begin{array}{l}\text { Carpesium abrotanoides } \mathrm{L} . \\
\text { 3378-KASH }\end{array}$ & Ban-sario & Herb & WL & Seed & Decoction & Oral & Indigestion & 12 & 0.34 \\
\hline & $\begin{array}{l}\text { Cichorium intybus L. } \\
2973-\mathrm{KASH}\end{array}$ & Kaw-hand & Herb & WL & Whole plant & Decoction & Oral & Diarrhea & 15 & 0.43 \\
\hline & $\begin{array}{l}\text { Conyza bonariensis }(\mathrm{L} .) \text { Cronquist } \\
3385-\mathrm{KASH}\end{array}$ & Shashedra & Herb & WL & Leaf & Infusion & Oral & Intestinal worms & 13 & 0.37 \\
\hline & Conyza canadensis (L.) Cronquist & Shal-lutt & Herb & WL & Root & Infusion & Oral & Dysentery & 14 & 0.40 \\
\hline
\end{tabular}


Ethnobotany Research and Applications

\begin{tabular}{|c|c|c|c|c|c|c|c|c|c|c|}
\hline & 2982-KASH & & & & & & & & & \\
\hline & $\begin{array}{l}\text { Lactuca saligna L. } \\
\text { 3406-KASH }\end{array}$ & Dodhkandiej & Herb & WL & Whole plant & Decoction & Oral & Diarrhea & 19 & 0.54 \\
\hline & $\begin{array}{l}\text { Tagetus erecta } \mathrm{L} . \\
\text { 3004-KASH }\end{array}$ & Guttaposh & Herb & WL & Flower & Infusion & Oral & Colic infection & 19 & 0.54 \\
\hline & $\begin{array}{l}\text { Xanthium spinosum L. } \\
\text { 3461-KASH }\end{array}$ & Lokut-cxeer & Herb & WL & Root & Decoction & Oral & Abdominal pain & 14 & 0.40 \\
\hline \multirow[t]{2}{*}{ Berberidaceae } & $\begin{array}{l}\text { Berberis lycium Royle } \\
\text { 2970-KASH }\end{array}$ & Kawdach & Shrub & WL & Fruit & Infusion & Oral & Diarrhea & 16 & 0.46 \\
\hline & $\begin{array}{l}\text { Podophyllum hexandrum Royle } \\
\text { 3429-KASH }\end{array}$ & Wanwangun & Herb & WL & Root & Decoction & Oral & Laxative & 12 & 0.34 \\
\hline \multirow[t]{2}{*}{ Brassicaceae } & $\begin{array}{l}\text { Capsella bursa-pastoris (L.) Medik } \\
\text { 2971-KASH }\end{array}$ & Kralmond & Herb & WL & Whole plant & Decoction & Oral & Vomiting & 15 & 0.43 \\
\hline & $\begin{array}{l}\text { Nasturtium officinale W.T. Aiton } \\
\text { 3419-KASH }\end{array}$ & Kulhakh & Herb & WL & Leaf & Decoction & Oral & Indigestion & 17 & 0.49 \\
\hline \multirow[t]{2}{*}{ Cannabaceae } & $\begin{array}{l}\text { Cannabis sativa L. } \\
\text { 3376-KASH }\end{array}$ & Bhangh & Herb & WL & Leaf & Infusion & Oral & Intestinal worms & 13 & 0.37 \\
\hline & $\begin{array}{l}\text { Celtis australis } \mathrm{L} . \\
\text { 3380-KASH }\end{array}$ & Brimij & Tree & WL & Fruit & Decoction & Oral & Colic infection & 14 & 0.40 \\
\hline Caprifoliaceae & $\begin{array}{l}\text { Sambucus wightiana Wall. } \\
\text { 3001-KASH }\end{array}$ & Gandula & Herb & WL & Fruit & Infusion & Oral & Stomach pain & 12 & 0.34 \\
\hline Chenopodiaceae & $\begin{array}{l}\text { Chenopodium album L. } \\
\text { 2972-KASH }\end{array}$ & Konh & Herb & WL & Leaf & Decoction & Oral & Diarrhea & 20 & 0.57 \\
\hline Convolvulaceae & $\begin{array}{l}\text { Convolvulus arvensis } \mathrm{L} . \\
\text { 3384-KASH }\end{array}$ & Haroli & Herb & WL & Leaf & Decoction & Oral & Constipation & 15 & 0.43 \\
\hline Cyperaceae & $\begin{array}{l}\text { Cyperus rotundus } \mathrm{L} . \\
\text { 3389-KASH }\end{array}$ & Gassh & Herb & WL & Whole plant & Decoction & Oral & Diarrhea & 13 & 0.37 \\
\hline Equisetaceae & $\begin{array}{l}\text { Equisetum arvense } \mathrm{L} . \\
\text { 2981-KASH }\end{array}$ & Bandakey & Herb & WL & Aerial portion & Infusion & Oral & Stomach pain & 18 & 0.51 \\
\hline \multirow[t]{2}{*}{ Fabaceae } & $\begin{array}{l}\text { Trifolium pratense } \mathrm{L} . \\
\text { 3454-KASH }\end{array}$ & Batak lautt & Herb & WL & Flower & Juice & Oral & Indigestion & 15 & 0.43 \\
\hline & $\begin{array}{l}\text { Trigonella foenum-graecum } \mathrm{L} . \\
\text { 3456-KASH }\end{array}$ & Meth & Herb & $\mathrm{CL}$ & Seed & Decoction & Oral & Indigestion & 21 & 0.60 \\
\hline \multirow[t]{2}{*}{ Geraniaceae } & $\begin{array}{l}\text { Erodium cicutarium (L.) L'Hér. ex } \\
\text { Aiton } \\
\text { 3393-KASH }\end{array}$ & Peinz ungajj & Herb & WL & Flower & Infusion & Oral & Constipation & 16 & 0.46 \\
\hline & $\begin{array}{l}\text { Geranium pratense } \mathrm{L} . \\
2985-\mathrm{KASH}\end{array}$ & Ringrish & Herb & WL & Leaf & Infusion & Oral & Diarrhea & 14 & 0.40 \\
\hline Hypericaceae & $\begin{array}{l}\text { Hypericum perforatum L. } \\
2988-\mathrm{KASH}\end{array}$ & Ring chai & Herb & WL & Leaf & Decoction & Oral & Abdominal pain & 16 & 0.46 \\
\hline
\end{tabular}


Ethnobotany Research and Applications

\begin{tabular}{|c|c|c|c|c|c|c|c|c|c|c|}
\hline \multirow[t]{8}{*}{ Lamiaceae } & $\begin{array}{l}\text { Ajuga bracteosa Wall. ex Benth. } \\
\text { 3356-KASH }\end{array}$ & Jani-adam & Herb & WL & Whole plant & Infusion & Oral & Abdominal pain & 23 & 0.66 \\
\hline & $\begin{array}{l}\text { Mentha aquatica } \mathrm{L} . \\
\text { 3416-KASH }\end{array}$ & Kul pudni & Herb & WL & Leaf & Infusion & Oral & Abdominal pain & 21 & 0.60 \\
\hline & $\begin{array}{l}\text { Mentha arvensis } \mathrm{L} . \\
3414-\mathrm{KASH}\end{array}$ & Pudni & Herb & $\mathrm{CL}$ & Leaf & Decoction & Oral & Stomach pain & 22 & 0.63 \\
\hline & $\begin{array}{l}\text { Mentha longifolia (L.) Huds. } \\
\text { 3415-KASH }\end{array}$ & Jangli pudni & Herb & WL & Leaf & Powder & Oral & Dysentery & 17 & 0.49 \\
\hline & $\begin{array}{l}\text { Nepeta cataria L. } \\
\text { 2993-KASH }\end{array}$ & Brair-gass & Herb & WL & Whole plant & Infusion & Oral & Diarrhea & 16 & 0.46 \\
\hline & $\begin{array}{l}\text { Origanum vulgare } \mathrm{L} . \\
3422-\mathrm{KASH}\end{array}$ & Wanbaber & Herb & WL & Seed & Infusion & Oral & Diarrhea & 15 & 0.43 \\
\hline & $\begin{array}{l}\text { Prunella vulgaris } \mathrm{L} . \\
2997-\mathrm{KASH}\end{array}$ & Kalweuth & Herb & WL & Leaf & Decoction & Oral & Diarrhea & 18 & 0.51 \\
\hline & $\begin{array}{l}\text { Stachys floccosa Benth. } \\
\text { 3645-(KASH) }\end{array}$ & NA & Herb & WL & Leaf & Infusion & Oral & Dysentery & 13 & 0.37 \\
\hline Liliaceae & $\begin{array}{l}\text { Gagea elegans Wall. ex G.Don. } \\
\text { 3615-(KASH) }\end{array}$ & NA & Herb & WL & Whole plant & Cooked & Oral & Indigestion & 16 & 0.46 \\
\hline \multirow[t]{4}{*}{ Malvaceae } & $\begin{array}{l}\text { Abutilon theophrasti Medik. } \\
\text { 3352-KASH }\end{array}$ & NA & Shrub & WL & Whole plant & Decoction & Oral & Diarrhea & 18 & 0.51 \\
\hline & $\begin{array}{l}\text { Hibiscus syriacus } \mathrm{L} . \\
\text { 3399-(KASH) }\end{array}$ & NA & Shrub & WL & Leaf & Infusion & Oral & Diarrhea & 12 & 0.34 \\
\hline & $\begin{array}{l}\text { Hibiscus trionum } \mathrm{L} . \\
\text { 3400-KASH }\end{array}$ & NA & Herb & WL & Leaf & Decoction & Oral & Stomach pain & 11 & 0.31 \\
\hline & $\begin{array}{l}\text { Malva neglecta Wall. } \\
\text { 2991-KASH }\end{array}$ & Sochal & Herb & WL & Leaf & Decoction & Oral & Stomach pain & 19 & 0.54 \\
\hline \multirow[t]{2}{*}{ Moraceae } & $\begin{array}{l}\text { Ficus carica L. } \\
\text { 3395-KASH }\end{array}$ & Anjeer & Tree & $\mathrm{CL}$ & Fruit & Infusion & Oral & Indigestion & 21 & 0.60 \\
\hline & $\begin{array}{l}\text { Ficus palmata Forssk. } \\
\text { 3396-KASH }\end{array}$ & Angeer & Tree & WL & Fruit & Juice & Oral & Abdominal pain & 20 & 0.57 \\
\hline Oxalidaceae & $\begin{array}{l}\text { Oxalis corniculata L. } \\
\text { 3423-KASH }\end{array}$ & Chuk-xanjj & Herb & WL & Whole plant & Infusion & Oral & Diarrhea & 15 & 0.43 \\
\hline Plantaginaceae & $\begin{array}{l}\text { Plantago lanceolata L. } \\
\text { 2995-KASH }\end{array}$ & Gull & Herb & WL & Leaf & Tea & Oral & Laxative & 19 & 0.54 \\
\hline Rosaceae & $\begin{array}{l}\text { Cyndonia oblonga Mill. } \\
\text { 2978-KASH }\end{array}$ & Bamchoont & Tree & $\mathrm{CL}$ & Seed & Decoction & Oral & Constipation & 23 & 0.66 \\
\hline Solanaceae & $\begin{array}{l}\text { Solanum tuberosum L. } \\
3451-\mathrm{KASH}\end{array}$ & Alua & Herb & $\mathrm{CL}$ & Tuber & Cooked & Oral & Acidity & 21 & 0.60 \\
\hline
\end{tabular}




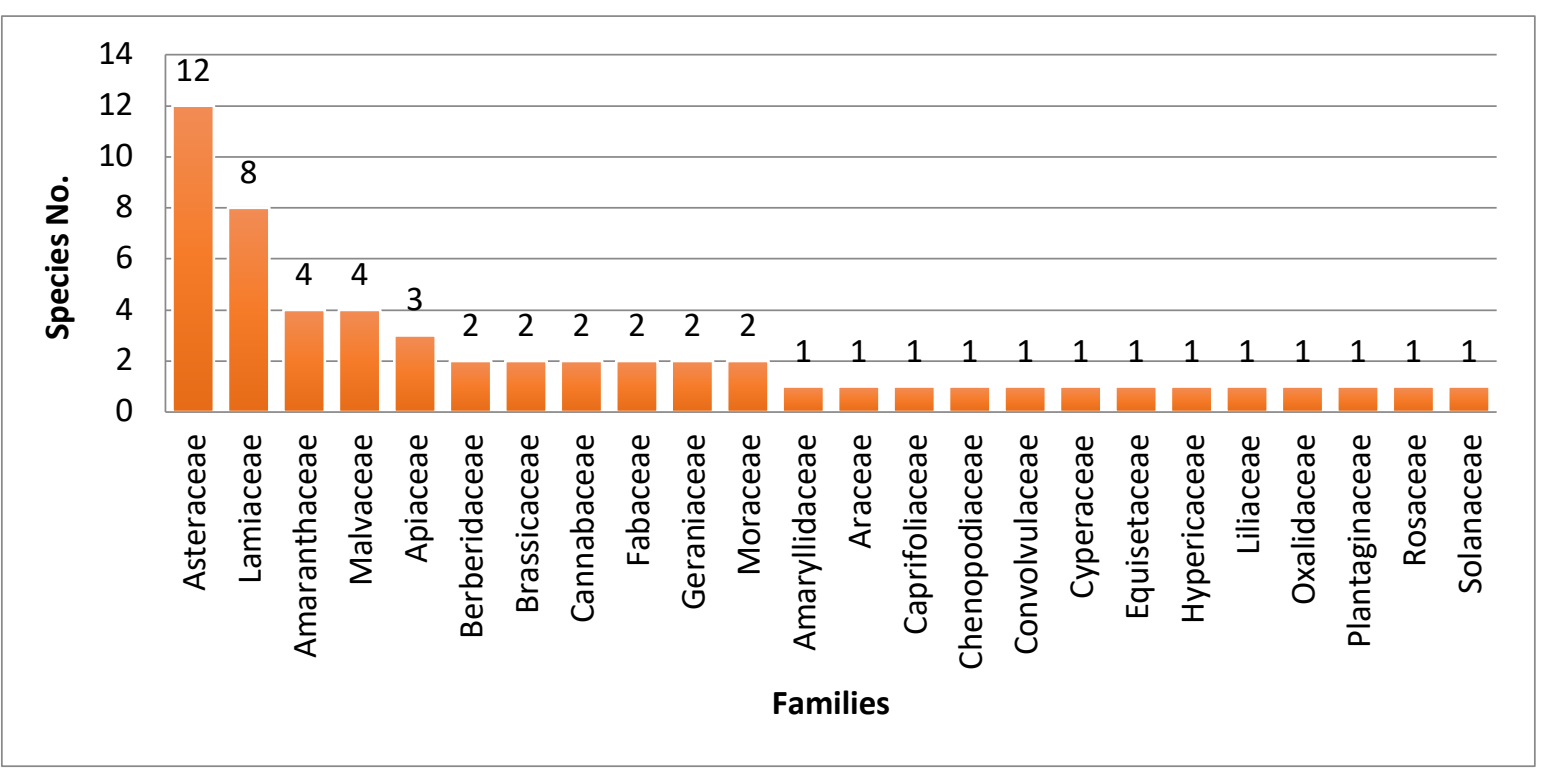

Figure 2. Contribution of different families to ethnomedicinal flora in the study area.

\section{Life form, parts used, and remedy preparation}

In the current study the most dominant life form used in the treatment of various ailments are herbs (49 species = $88 \%$ ), followed by trees (4 species $=7 \%$ ), and shrubs (3 species $=5 \%$ ) (Fig. 3).

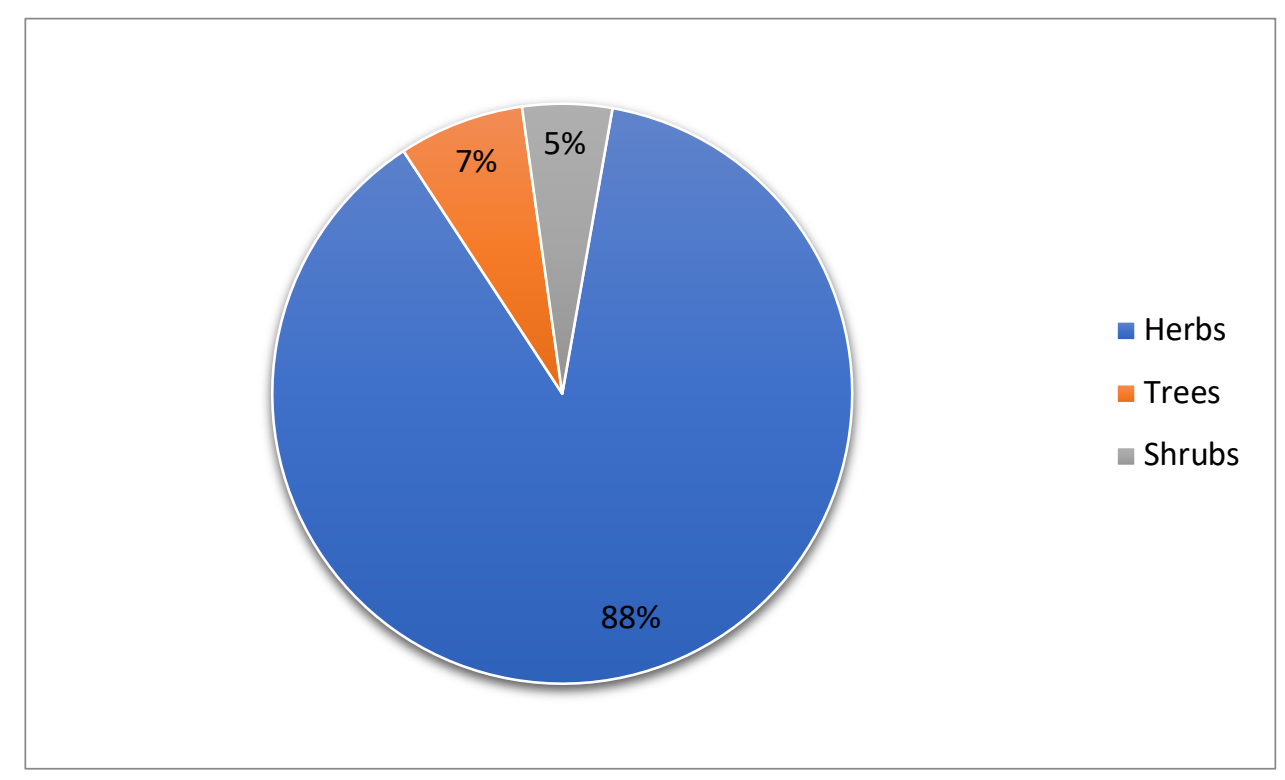

Figure 3. Distribution of species according to their life form.

The reason behind the use of herbs might be due to the presence of high content of bio-active compounds in them (Giday et al. 2009; Mesfin et al. 2009; Lulekal et al. 2013) and also their medicinal action is more effective than other forms of plant (Adnan et al. 2012; Adnan et al. 2014). Herbs also grow mostly along roadsides and in home gardens, so are easily available in nature to collect (Shrestha and Dhillion 2003; Kayani et al. 2014). Leaves (39\%) were found the most commonly plant part used followed by whole plant (21\%), seeds and fruits (9\% each) and roots (7\%) (Fig. 4). I n line with the current study leaves were reported to be the dominant part in various other previous studies (Giday et al. 2003; Bhatia et al. 2014; Shah et al. 2016). The reason behind the frequent use of leaves may be because leaf acts as the center of photosynthesis and other metabolic activities and hence most of the secondary metabolites are formed in leaves (Verpoorte et al. 2002; Ghorbani 2005; Cakilcioglu and Turkoglu 2010; Jan et al. 2021a, b). Also, it is easy to collect and to prepare medicinal remedies from leaves rather than other parts of the plant. It has also been reported that consumption of leaves is a sustainable collection of medicinal part 
as it is not needed to uproot the whole plant and hence this use adds to the conservation of medicinal plants (Giday et al. 2003).

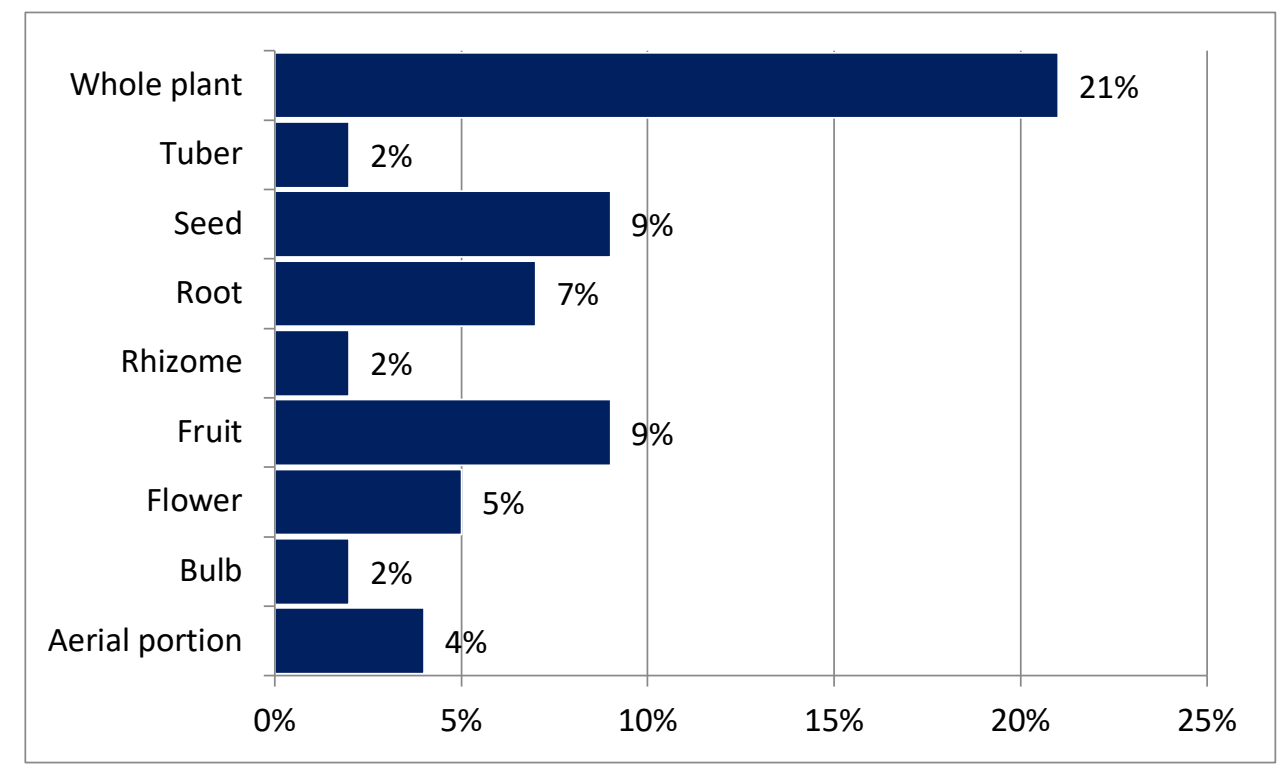

Figure 4. Percentage contribution of plant parts used.

In the current study decoction (41\%), was found to be the most common method of preparation of herbal medicines followed by infusion (37\%), cooked and juice (7\% each), powder (4\%), raw, and tea (2\% each) (Fig. 5). The preference and preparation were based on the potency and shelf life of the remedy (Sonibare and Abegunde 2012). All the herbal drugs were used by oral means in the present study. In line with our studies, ethnic people in various parts of Kashmir Himalaya and other parts of the world use herbal medicine orally (Mahmood et al. 2012; Mir et al. 2021).

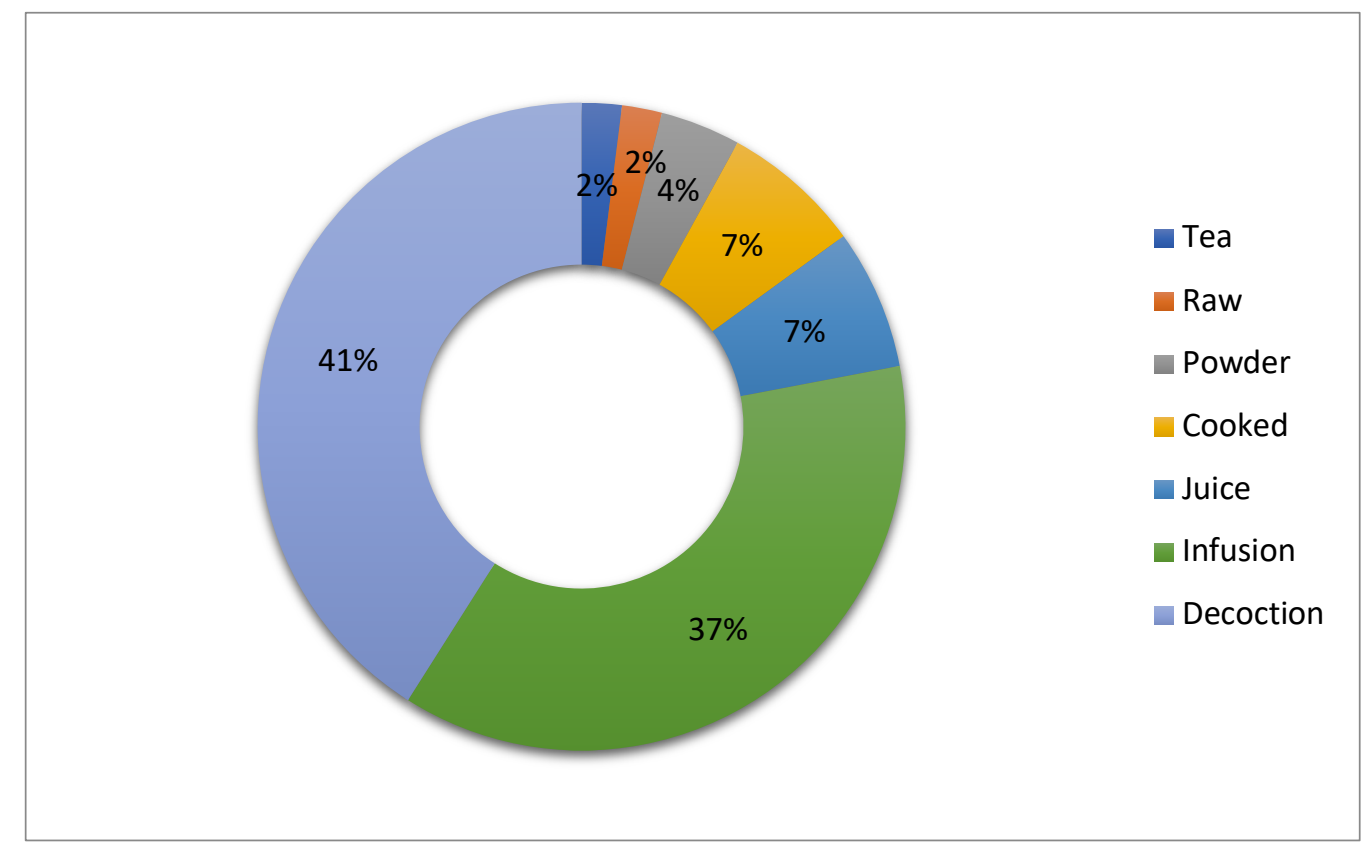

Figure 5. Percentage contribution of herbal recipes.

It was also reported from the informants that sometimes the higher doses may cause serious implications or even death of the soul. If not taken in proper doses these plants may pose adverse effects on the human body. That is why, one need to be more sensitive while using the herbal medicinal plants at home. 


\section{Informant consensus factor (ICF)}

The aim of using ICF in this study was to ascertain the agreement of informants for the cure of an ailment category. This value explains the cultural consistency for the use of a group of therapeutic plants to cure a group of a particular ailment categories (Heinrich et al. 2009). In the current study, all the ailments were categorized into 11 different ailment categories to calculate the value of ICF. From the obtained results, highest ICF value of 1 was recorded for vomiting (15 use reports and 1 taxa) and the lowest ICF value of 0.94 (210 use reports and 13 taxa) was recorded for diarrhea (Table 3).

Table 3. Value of informant consensus factor (ICF) for each disease category.

\begin{tabular}{|l|l|l|l|}
\hline Disease category & Nur & Nt & ICF \\
\hline Diarrhea & 210 & 13 & 0.94 \\
\hline Dysentery & 102 & 6 & 0.95 \\
\hline Stomach pain & 133 & 8 & 0.95 \\
\hline Indigestion & 124 & 7 & 0.95 \\
\hline Constipation & 97 & 5 & 0.96 \\
\hline Abdominal pain & 130 & 6 & 0.96 \\
\hline Intestinal worms & 52 & 3 & 0.96 \\
\hline Colic infection & 43 & 2 & 0.97 \\
\hline Laxative & 31 & 2 & 0.97 \\
\hline Acidity & 33 & 2 & 0.97 \\
\hline Vomiting & 15 & 1 & 1 \\
\hline
\end{tabular}

Most of the informants reported Amaranthus caudatus, Cichorium intybus, Lactuca saligna, Berberis lycium, Nepeta cataria, Origanum vulgare, Prunella vulgaris, Abutilon theophrasti, and Oxalis corniculata to be more useful in the treatment of diarrhea.

The results reported in our study are in line with the similar studies conducted in various other parts of the world (Jan et al. 2020), where vomiting was also reported with highest ICF value. High ICF indicates that a small number of plants used to treat ailment and is well communicated among the informants in the study area to treat ailments by that species. This in turn might indicate the effectiveness of the plant species for the treatment of specific disease categories and indicates the possibility of presence of biologically active components in these plants (Cakilcioglu et al. 2011). It has been suggested that high ICF values are related to high plant use values for one disease category (Madikizela et al. 2012). In quantitative ethnobotanical studies, analysis of data by different ethnobotanical indices provides a well-defined criterion to define the traditional knowledge of medicinal plant species in the local population of the area (Kadir et al. 2014).

\section{Use value (UV)}

The use value index is used to find out the relative importance of medicinal plants in the study area. Its value ranges from $0-1$. The medicinal plants with more use reports have high use value and medicinal plants with fewer use reports have low use value. In the current study the highest UV of 0.74 was calculated for Artemisia absinthium and the lowest UV of 0.31 for Hibiscus trionum (Table 2). As we can't ignore the medicinal plants with high use value, therefore, the medicinal plants with low use values should not be ignored as failing to provide this information to future generation could raise the threat of vanishing of this valuable knowledge (Ahmad et al. 2015). In addition, it is not true that medicinal plants with low use values are less important, but it indicates that the knowledge of these medicinal plants is at risk or availability of the particular medicinal plant is less (Chaudhary et al. 2006; Mahmood et al. 2013). The high UV of medicinal plants in the study region is attributed to their common distribution in the area and the local people are well familiar of their medicinal uses (Rahman et al. 2016). Several phytochemical substances have been extracted and reported from Artemisia absinthium including, sesquiterpene lactones, a class of natural compounds with several proved medicinal effects, guanolide dimmers as absinthin and its isomers anabsinthin, anabsin, artabsin and absintholide (Beauhaire et al. 1984), germacrene type as artabin (Akhmedov et al. 1970), matricin, beta-santonin and ketopepenolid-A (Perez-Souto et al. 1992). Due to the presence of these phytochemical constituents the plant has been reported to show Hyper-secretary activity (Blumberger and Glatzel 1966), Antiulcer activity (Shafi et al. 2004)), Neuroprotective activity (Wake et al. 2000), Anthelmintic activity (Meschler and Howlett 1999), Neurotoxic activity (Donald 1981), Antiprotozoal activity (Valdes et al. 2008), Antifungal activity (Essawi and Srour 2000) and Anti-microbial activity (Kordali et al. 2005). Artemisia absinthium, Achyranthes aspera, Ajuga bracteosa, Cyndonia oblonga, Ficus palmata, Ficus carica, Mentha arvensis, Mentha aquatic, Trigonella foenum-graecum, Chenopodium album, Foeniculum vulgare, Daucus carota, Coriandrum sativum, Amaranthus spinosus, and Amaranthus blitum were among the high use value medicinal plants used for the treatment of gastrointestinal disorders.

\section{Novelty of the study}

To the best of our knowledge, it is the first independent study of its kind in the area and the region. The current research focuses on the safe and effective use of medicinal plants against various gastrointestinal disorders. Our results coincide with other ethnobotanical studies in the region and around the world to some extent; however, 
this study revealed a total of 56 medicinal plants used against various gastrointestinal disorders. The data revealed that the type of plant used, the method by which indigenous people prepare crude drugs, and how they are administered vary significantly across the region and globally, offering new ethnomedicinal information. Being the first study on medicinal plants used against various gastrointestinal disorders, present study offers baseline data for researchers for future phytochemical investigations and would provide insights that could help to raise and improve local healthcare. Furthermore, it might provide a source of income for communities and have a positive impact on socioeconomic conditions, all with the purpose of preserving these natural treasures.

\section{Conclusion}

Medicinal flora forms the pillar of our traditional healthcare structure with a huge part of population still dependent on traditional medicines in most of the developing countries. Present study was an attempt to underline the potential medicinal plants used against various gastrointestinal disorders in district Budgam of Jammu and Kashmir. During the study 56 different medicinal plants belonging 24 families and 47 genera were reported from the study area. It can be concluded from present research that people of the study area possess a rich traditional knowledge inherited from their forefathers and documentation of this valuable knowledge has provided novel information from the area. Native populations still rely on medicinal plants for their primary health care, but at the same time are alarmed about the degradation of the flora in wild. It was found that the elderly people possessed a great wealth of indigenous knowledge in comparison to the younger ones, this difference in knowledge might be due to the changing lifestyle of younger folk, changing views of ethnic communities and the increasing influence of industrialization, due to which traditional medicinal knowledge of plant species is frequently vanishing at an alarming rate. Therefore, there is a need to speedily document the important plants and associated knowledge and to take necessary measures for the conservation of these resources so as to save this treasure; otherwise, a great number of medicinally important plants will become extinct in wild. To validate this indigenous knowledge, we suggest that species with high use value (UV) be used for future phytochemical and pharmacological investigation.

\section{Declarations}

List of abbreviations: CL-Cultivated, WL-Wild, NA-Not available.

Ethics approval and consent to participate: This ethnomedicinal study was approved by the ethical committees of the Department of Botany, Government Model Science College, Jiwaji University, Gwalior, India. Before conducting interviews, individual prior informed consent was obtained from all participants. No further ethics approval was required. All work conducted was carried out under the stipulations of the Nagoya Protocol on Access to Genetic Resources and the Fair and Equitable Sharing of Benefits Arising from their Utilization to the Convention on Biological Diversity. The right to use and authorship of any traditional knowledge of all participants is maintained, and any use of this information, other than for scientific publication, does require the additional prior consent of the traditional owners, as well as a consensus on access to benefits resulting from subsequent use.

Consent for publication: Not applicable-no personal data is included in this manuscript.

Availability of data and materials: The data used to support the findings of this study are available from the corresponding author upon request.

Competing interests: The authors declare no competing interests.

Funding: This study has not received any grant/funding from any agencies or forum.

Author's contributions: Tawseef Ahmad Mir: Visualization, Supervision, Methodology, Formal analysis, Writingoriginal draft. Rakesh Kumar Khare: Visualization, Supervision, Writing-review \& editing. Muatasim Jan: Methodology, Formal analysis, Writing-original draft, Proof-reading.

\section{Acknowledgments}

The authors are thankful to management of Government Model Science College, Jiwaji University, Gwalior, India for providing necessary facilities and support to carry out this study as a part of the doctoral degree. Authors are highly thankful to our parents and family for their endless support all the time. Authors are highly grateful to local population of district Budgam, Jammu and Kashmir for sharing their indigenous medicinal plant knowledge. Authors are grateful to Mr. Akhtar H. Malik (Curator KASH Herbarium/Junior scientist, University of Kashmir) for helping in the identification of plant species. Dr. Aijaz Hassan (KU campus, Kargil) is also acknowledged here for his consistent support and guidance during the manuscript writing. Authors also acknowledge the help provided by Mr. Harikesh (IIRS, Dehradun), Sofiya Anjum (GBPNIHE, Almora) and Shiekh Anneus (University of Kashmir, Srinagar) in the form required maps of the study area. We would like to thank and appreciate the handling/section editor of Ethnobotany Research and Applications, Dr. Biswajit Bose for speedy review of our paper and the 
anonymous reviewers for their critical comments and helpful suggestions which highly improved the scientific merit of this manuscript.

\section{Literature cited}

Acharyya S, Patra A, Bag PK. 2009. Evaluation of the antimicrobial activity of some medicinal plants against enteric bacteria with particular reference tomulti-drug resistant Vibrio cholera. Tropical Journal of Pharmaceutical Research 8(3):231-237.

Adnan M, Begum S, Khan AL, Tareen AM, Lee IJ. 2012. Medicinal plants and their uses in selected temperate zones of Pakistani Hindukush-Himalaya. Journal of Medicinal Plants Research 6(24):4113-4127.

Adnan M, Ullah I, Tariq A, Murad W, Azizullah A, Khan AL, Ali N. 2014. Ethnomedicine use in the war affected region of northwest Pakistan. Journal of Ethnobiology and Ethnomedicine 10(1):16.

Ahmad K, Pieroni A. 2016. Folk knowledge of wild food plants among the tribal communities of Thakhte- Sulaiman Hills, North-West Pakistan. Journal of Ethnobiology and Ethnomedicine 12(1):17.

Ahmad L, Qayoom S. 2019. Precipitation and Rainy Day Trends in Kashmir Valley, Jammu \& Kashmir, India. Indian Journal of Ecology 46(1):83-87.

Ahmad L, Semotiuk A, Zafar M, Ahmad M, Sultana S, Liu QR, Yaseen G. 2015. Ethnopharmacological documentation of medicinal plants used for hypertension among the local communities of DIR Lower, Pakistan. Journal of Ethnopharmacology 175:138-146.

Akhmedov IS, Kasymov SZ, Sidyakin GP. 1970. Artabin-a new lactone from Artemisia absinthium. Chemistry of Natural Compounds 1970, 6:634.

Ayantunde AA, Briejer M, Hiernaux P, Udo HM, Tabon R. 2008. Botanical knowledge and its differentiation by age, gender and ethnicity in Southwestern Nigeria. Human Ecology 36(6):881-889.

Bahukhandi A, Rawat S, Jugran AK, Bhatt ID, Rawal RS. 2021. Seasonal Variation in Phenolics and Antioxidant Activity of Acorus calamus Linn.: An Important Medicinal Plant of Himalaya. National Academy Science Letters 44:13-15.

Beauhaire J, Fourrey JL, Guittet E. 1984. Structure of absintholide a new guaianolide dimer of Artemisia absinthium L. Tetrahedron Letters 25:2751-2754.

Bhatia H, Sharma YP, Manhas RK, Kumar K. 2014. Ethnomedicinal plants used by the villagers of district Udhampur, J\&K, India. Journal of Ethnopharmacology 151(2):1005-1018.

Blumberger W, Glatzel H. 1966. Contributions to the physiology of spices and condiments. VII. Research on the mechanism of action on salivary gland function. Nutritio et dieta; European review of nutrition and dietetics 8(2):145-160.

Bolson M, Hefler SA, Chaves EID, Junior AG, Junior ELC. 2015. Ethno-medicinal study of plants used for treatment of human ailments, with residents of the surrounding region of forest fragments of Paraná, Brazil. Journal of Ethnopharmacology 161:1-10.

Cakilcioglu U, Turkoglu I. 2010. An ethnobotanical survey of medicinal plants in Sivrice (Elazığ-Turkey). Journal of Ethnopharmacology 132(1):165-175.

Chaudhary MI, He Q, Cheng YY, Xiao PG. 2006. Ethnobotany of medicinal plants from tian mu Shan biosphere reserve, Zhejiang-province, China. Asian Journal of Plant Sciences 5(4):646-653.

Donald DV. 1981. Artemisia Absinthiumr. a nineteenth-century drug of abuse. Journal of Ethnopharmacology 4:337343.

Essawi T, Srour M. 2000. Screening of some Palestinian medicinal plants for antibacterial activity. Journal of Ethnopharmacology 70:343-349.

Ghorbani A. 2005. Studies on pharmaceutical ethnobotany in the region of Turkmen Sahra, north of Iran:(Part 1): General results. Journal of Ethnopharmacology 102(1):58-68.

Giday M, Asfaw Z, Elmqvist T, Woldu Z. 2003. An ethnobotanical study of medicinal plants used by the Zay people in Ethiopia. Journal of Ethnopharmacology 85(1):43-52. 
Giday M, Asfaw Z, Woldu Z. 2009. Medicinal plants of the Meinit ethnic group of Ethiopia: an ethnobotanical study. Journal of Ethnopharmacology 124(3):513-521.

Giday M, Teklehaymanot T, Animut A, Mekonnen Y. 2007. Medicinal plants of the Shinasha, Agew-awi and Amhara peoples in northwest Ethiopia. Journal of Ethnopharmacology 110 (3):516-525.

Gogtay NJ, Bhatt HA, Dalvi SS, Kshirsagar NA. 2002. The use and safety of non-allopathic Indian medicines. DrugSafety 25:1005-1019.

Hamill FA, Apio S, MubirU NK, Mosango M, Bukenya-Ziraba R, Maganyi OW, Soejarto DD. 2000. Traditional herbal drugs of Southern Uganda. Journal of Ethnopharmacology 70(3):281-300.

Heinrich M, Ankli A, Frei B, Weimann C, Sticher O. 1998. Medicinal plants in Mexico: Healers' consensus and cultural importance. Social Science and Medicine 47:1863-1875.

Heinrich M, Sarah E, Daniel EM, Marco L. 2009. Ethnopharmacological field studies: a critical assessment of their conceptual basis and methods. Journal of Ethnopharmacology 124(1):1-17.

Hocking GM. 1958. Pakistan medicinal plants I. Qualitas Plantarum et Materiae Vegetabiles 5(1-2):145-153.

Holst L, Nordeng H, Haavik S. 2008. Use of herbal drugs during early pregnancy in relation to maternal characteristics and pregnancy outcome. Pharmacoepidemiology and Drug Safety 17(2):151-159.

http://www.theplantlist.org

Hussain Al, Anwar F, Rasheed S, Nigam PS, Janneh O, Sarker SD. 2011. Composition, antioxidant and chemotherapeutic properties of the essential oils from two Origanum species growing in Pakistan. Revista Brasileira de Farmacognosia 21(6):943-952.

Ibrar M, Hussain F, Sultan A. 2007. Ethnobotanical studies on plant resources of Ranyal Hills, District Shangla, Pakistan. Pakistan Journal of Botany 39(2):329-337.

Ishtiyak P, Hussain SA. 2017. Traditional Use of Medicinal Plants among Tribal Communities of Bangus Valley, Kashmir Himalaya, India. Ethnomedicine 11(4):318-331.

Jain SK, Rao RR. 1977. A Handbook of Field and Herbarium Methods. Today and Tomorrow's Printer, New Delhi, India. 157.

Jan HA, Jan S, Bussmann RW, Ahmad L, Wali S, Ahmad N. 2020. Ethnomedicinal survey of the plants used for gynecological disorders by the indigenous community of district Buner, Pakistan. Ethnobotany Research \& Applications 19(26):1-18.

Jan HA, Wali S, Ahmad L, Jan S, Ahmad, N, Ullah N. 2017. Ethnomedicinal survey of medicinal plants of Chinglai valley, Buner district, Pakistan. European Journal of Integrative Medicine 13:64-74.

Jan M, Khare RK, Mir TA. 2021a. Ethnomedicinal Appraisal of Medicinal Plants from Family Asteraceae used by the Ethnic Communities of Baramulla, Kashmir Himalaya. Indian Forester 147(5):475-480.

Jan M, Mir TA, Ganie AH, Khare RK. 2021b. Ethnomedicinal use of some plant species by Gujjar and Bakerwal community in Gulmarg Mountainous Region of Kashmir Himalaya. Ethnobotany Research and Applications 21(38):1-23.

Jeelani SM, Rather GA, Sharma A, Lattoo SK. 2018. In perspective: Potential medicinal plant resources of Kashmir Himalayas, their domestication and cultivation for commercial exploitation. Journal of Applied Research on Medicinal and Aromatic Plants 8:10-25.

Kadir MF, Bin Sayeed MS, Setu NI, Mostafa A, Mia MM. 2014. Ethnopharmacological survey of medicinal plants used by traditional health practitioners in Thanchi, Bandarban Hill Tracts. Bangladesh Journal of Ethnopharmacology 155(1):495-508.

Kayani S, Ahmad M, Zafar M, Sultana S, Khan MPZ, Ashraf MA, Yaseen G. 2014. Ethnobotanical uses of medicinal plants for respiratory disorders among the inhabitants of Gallies-Abbottabad, Northern Pakistan. Journal of Ethnopharmacology 156:47-60. 
Kordali S, Kotan R, Mavi A, Cakir A, Ala A, Yildirim A. 2005. Determination of the chemical composition and antioxidant activity of the essential oil of Artemisia dracunculus and of the antifungal and antibacterial activities of Turkish Artemisia absinthium, A. dracunculus, Artemisia santonicum, and Artemisia spicigera essential oils. Journal of Agricultural and Food Chemistry 53(24): 9452-9458.

Leonti MM, Pamirez F, Sticher O, Heinrich M. 2003. Medicinal flora of the Populuca: a botanical systematical perspective. Economic Botany 57:218-230.

Levy PS, Lemeshow S. 2008. Sampling of populations. Methods and Applications, New York: John Wiley Sons.

Lulekal E, Asfaw Z, Kelbessa E, Van Damme P. 2013. Ethnomedicinal study of plants used for human ailments in Ankober District, North Shewa Zone, Amhara region, Ethiopia. Journal of Ethnobiology and Ethnomedicine 9(1):63.

Madikizela B, Ndhlala AR, Finnie JF, Staden VJ. 2012. Ethnopharmacological study of plants from Pondoland used against diarrhea. Journal of Ethnopharmacology 141:61-71.

Mahmood A, Mahmood A, Malik RN, Shinwari ZK. 2013. Indigenous knowledge of medicinal plants from Gujranwala district, Pakistan. Journal of Ethnopharmacology 148(2):714-723.

Mahmood RR, Mahmood Malik. 2012. Indigenous knowledge of medicinal plants from Leepavally Azad Jammu and Kashmir, Pakistan. Journal of Ethnopharmacology 143:338-346.

Martin GJ. 1995. Ethnobotany: A ‘People and Plants' Conservation Manual, Chapman and Hall, London.

Mehdioui R, Kahouadji A. 2007. Etude ethnobotanique auprès de la population riveraine de la forêt d'Amsittène: cas de la Commune d'Imi n'Tlit (Province d'Essaouira). Bulletin de l'Institut scientifique, Rabat, section Sciences de la vie 29:11-20.

Meschler JP, Howlett AC. 1999. Thujone exhibits low affinity for cannabinoid receptors but fails to evoke cannabimimetic responses. Pharmacology Biochemistry and Behavior 62:413-480.

Mesfin F, Demissew S, Teklehaymanot T. 2009. An ethnobotanical study of medicinal plants in Wonago Woreda, SNNPR, Ethiopia. Journal of Ethnobiology and Ethnomedicine 5(1):28.

Mir TA, Jan M, Khare RK, Dhyani S. 2021. Ethno-Survey of Traditional Use of Plants in Lolab Valley, Kashmir Himalaya. Indian Forester 147(3):281-287.

Msomi NZ, Simelane MBC. 2019. Herbal Medicine. Herbal Medicine doi:10.5772/intechopen.72816.

Nour SA, Rosli HA, Oluwaseun MY, Olalere RA, Abayomi O. 2019. Extraction, characterization and antioxidant activity of fenugreek (Trigonella-Foenum graecum) seed oil. Materials Science for Energy Technologies 2(2):349355.

Perez-Souto N, Lynch RJ, Measures G, Hann JT. 1992. Use of high-performance liquid chromatographic peak deconvolution and peak labelling to identify antiparasitic components in plant extracts. Journal of Chromatography 593:209-215.

Phillips O, Gentry AH. 1993. The useful plants of Tambopata, Peru: i. Statistical hypotheses tests with a new quantitative technique. Economic Botany 47:15-32.

Polunin O, Stainton A.1984. Flowers of the Himalayas. Oxford University Press, Delhi.

Rahman IU, ljaz F, lqbal Z, Afzal A, Ali N, Afzal M, Asif M. 2016. A novel survey of the ethno medicinal knowledge of dental problems in Manoor Valley (Northern Himalaya), Pakistan. Journal of Ethnopharmacology 194:877-894.

Savikin K, Zdunic G, Menokovic N, Zivkovic J, Ujic N, Terescenko M, Bigovic D. 2013. Ethnobotanical study on traditional use of medicinal plants in South Western Serbia, Zlatibor district. Journal of Ethnopharmacology 146:803-810.

Shafi N, Khan GA, Ghauri EG. 2004. Antiulcer effect of Artemisia absinthium L. in rats. Pakistan Journal of Scientific and Industrial Research 47(2):130-134.

Shah SA, Shah NA, Ullah S, Alam MM, Badshah H, Ullah S, Mumtaz AS. 2016. Documenting the indigenous knowledge on medicinal flora from communities residing near Swat River (Suvastu) and in high mountainous areas in Swat-Pakistan. Journal of Ethnopharmacology 182:67-79. 
Shedayi AA, Gulshan B. 2012. Ethnomedicinal uses of plant resources in Gilgit-Baltistan of Pakistan. Journal of Medicinal Plants Research 6(29):4540-4549.

Shrestha PM, Dhillion SS. 2003. Medicinal plant diversity and use in the highlands of Dolakha district, Nepal. Journal of Ethnopharmacology 86(1):81-96.

Singh JB, Kachroo P. 1994. Forest Flora of Pir Panjal Range (North Western Himalaya). Bishen Singh Mahendra Pal Singh, Dehradun, India.

Singh NP, Singh DK, Uniyal BP. 2002. Flora of Jammu \& Kashmir: Pteridophytes Gymnosperms and Angiosperms, Vol. 1. Botanical Survey of India, New Delhi, India.

Sonibare M.A, Abegunde RB. 2012. Ethnobotanical study of medicinal plants used by the Laniba village people in South Western Nigeria. African Journal of Pharmacy and Pharmacology 6(24):1726-1732.

Taber KS. 2018. The use of cronbach's alpha when developing and reporting research instruments in science education, Research in Science Education 48(6):1273-1296.

Tali BA, Khuroo AA, Ganie AA, Nawchoo IA. 2019. Diversity, distribution and traditional uses of medicinal plants in Jammu and Kashmir (J\&K) state of Indian Himalayas. Journal of Herbal Medicine. https://doi.org/10.1016/j.hermed.2019.100280.

Tariq A, Adnan M, Iqbal A, Sadia S, Fan Y, Nazar A, Mussarat S, Ahmad M, Olatunji OA, Begum S, Mazari P, Ambreen B, Khan SN, Ullah R, Khan AL. 2018. Ethnopharmacology and toxicology of Pakistani medicinal plants used to treat gynecological complaints and sexually transmitted infections. South African Journal of Botany 114:132-149.

Valdes AFC, Martinez JM, Lizama RS, Vermeersch M, Cos P, Maes L et al. 2008. In vitro anti-microbial activity of the Cuban medicinal plants Simarouba glauca DC, Melaleuca leucadendron L. and Artemisia absinthium L. Memorias do Instituto Oswaldo Cruz 103:615-618.

Verpoorte R, Contin A, Memelink J. 2002. Biotechnology for the production of plant secondary metabolites. Phytochemistry Reviews 1(1):13-25.

Wake G, Court J, Pickering A, Lewis R, Wilkins R, Perry E et al. 2000. CNS acetylcholine receptor activity in European medicinal plants traditionally used to improve failing memory. Journal of Ethnopharmacology 69:105-114.

Woods AB. 1991. Nurse-midwifery in rural Pakistan. Journal of Nurse-Midwifery 36(4):249-252. 